\title{
Progranulin: A proangiogenic factor in visceral adipose tissue in tumoral and non-tumoral visceral pathology
}

\author{
IOANA BINIȘOR ${ }^{1 *}$, ILEANA MONICA BANIȚ $\breve{A}^{1}$, DRAGOȘ ALEXANDRU ${ }^{2 *}$, MIHAELA CEZARINA MEHEDINȚI ${ }^{3 *}$, \\ SANDA JURJA $^{4 *}$, ANA-MARINA ANDREI ${ }^{5}$ and CĂTĂLINA GABRIELA PISOSCHI ${ }^{5}$ \\ Departments of ${ }^{1}$ Histology and ${ }^{2}$ Medical Informatics and Biostatistics, University of Medicine and Pharmacy \\ of Craiova, 200349 Craiova; ${ }^{3}$ Department of Histology, 'Dunărea de Jos' University of Galați, 80010 Galați; \\ ${ }^{4}$ Department of Ophthalmology, 'Ovidius' University of Constanta, 900470 Constanta; ${ }^{5}$ Department of \\ Biochemistry, University of Medicine and Pharmacy of Craiova, 200349 Craiova, Romania
}

Received July 23, 2021; Accepted August 23, 2021

DOI: $10.3892 /$ etm.2021.10772

\begin{abstract}
The connection between central obesity and the development and metastasis of various visceral tumors is largely accepted and one of the main causes seems to be the local synthesis of proangiogenic molecules. Progranulin (PRG), recently identified as an adipokine, is a novel pleiotropic growth factor acting on the proliferation and development of fast-growing epithelial cells, cancer cells, and also a proangiogenic factor whose expression is induced in activated endothelial cells. One of the molecules that seems to trigger the angiogenic activity of PRG is vascular endothelial growth factor (VEGF). Two groups of human subjects were considered and adipose tissue was processed for an immunohistochemical and morphometric study after surgery for abdominal tumoral or non-tumoral pathology. The presence of PRG in adipose pads of the omentum was analyzed and its association with VEGF, CD34 and collagen IV in tumoral and non-tumoral visceral pathology was examined. The results showed that PRG but not VEGF expression was upregulated in adipose tissue in tumoral visceral pathology. In conclusion, the involvement of the proangiogenic activity of PRG and VEGF in adipose tissue under tumor conditions may be dependent on the visceral tumor type.
\end{abstract}

\section{Introduction}

Adipose tissue which is widespread in humans is comprised of $50 \%$ of completely developed adipocytes (1) while the

Correspondence to: Professor Ileana Monica Baniță, Department of Histology, University of Medicine and Pharmacy of Craiova, 2-4 Petru Rares Street, 200349 Craiova, Romania

E-mail: monica.banita@umfcv.ro

${ }^{*}$ Contributed equally

Key words: omental adipose tissue, visceral tumors, progranulin, VEGF, collagen IV, CD34 remaining $50 \%$ of adipose tissue consists of a complex population of immature adipocytes, proinflammatory cells (macrophages and lymphocytes) and fully differentiated cells such as endothelial and nerves cells. Two major adipose tissue varieties are described, with different cell phenotype and functions: white adipose tissue (WAT) and brown adipose tissue (BAT), the latter being well developed in newborns and small mammals, with its major function being thermoregulation as well as playing an anti-obese role (2-5).

As a result of the heterogeneity of their structure and function, adipose tissues are now considered to form a complex organ provided with metabolic, endocrine and immunologic functions (6-8). The normal metabolic functions of WAT and their disruption involve a mediated crosstalk between adipocytes and cells from the stromo-vascular fraction (SVF). This crosstalk is made possible by the active secretion of adipokines or adipocytokines from the adipose tissue with metabolic and pro/anti-inflammatory effects (9). As a consequence, there is a direct link between obesity, cardiovascular diseases and in the last 10 years cancer development $(1,10,11)$.

The development of metabolic syndrome and cancer are not dependent on the total amount of WAT in an organism, but rather on the distribution of the fat depots $(7,12)$. Visceral adipose tissue accumulation leading to central obesity is accepted as a source of inflammatory molecules as well as 'oncogenic fat' (11), whereas subcutaneous adipose tissue is usually considered to be protective (13). The list of central obesity-related cancers is in active extension, most of which are hosted in the visceral area (gastric, endometrial, ovarian, colorectal, prostatic, renal, liver, gallbladder or esophageal) $(11,14,15)$. Two main mechanisms connect visceral fat to visceral cancer: i) the dysregulation of metabolism (through the increase in insulin secretion and insulin growth factor synthesis in WAT) (16) and ii) mild chronic inflammation $(17,18)$.

At present, two important findings connect undoubtedly visceral fat to visceral cancer: the most common site for ovarian cancer metastasis is the epiploon, and primary human omental adipocytes induce in vitro cell proliferation and invasion for the majority of visceral tumors $(19,20)$. 
Even if cancer-associated adipocytes are demonstrated to supply energy for tumor development, the role of visceral adipose tissue from obese or lean subjects in priming tumor development is still under debate.

The adipose tissue is one of the most plastic organs in adults gifted with the ability of continuous remodeling, expanding or retracting according to the energetic balance. Being a compulsory condition for the expansion of any tissue in order to provide the substances requested for its survival, angiogenesis may be considered in a mechanistic approach, a common feature of adipose and tumor tissue. WAT secretome includes various pro-angiogenic hormones, cytokines, and growth factors secreted by the stromo-vascular cells, namely endothelial cells, and also by adipocytes and preadipocytes (21-23). Visceral WAT is more vascularized (24). It expresses more adipokines with angiogenic activity, endothelial cells exhibit more potent angiogenic molecules and newly emerging adipocytes in obese conditions are highly angiogenic (25). These are added to the substances elaborated by the proinflammatory and mesenchymal cells resident in the stromovascular fraction of the adipose depots, mainly growth factors (26-28). Adipokines lead to the establishment of a proangiogenic milieu.

However, it is not clear whether all the substances secreted by the adipose tissue may have a paracrine or an endocrine effect on visceral tumor initiation and progression, but the proangiogenic factors may be truly incriminated, as angiogenesis is a major common event required both for tumor and adipose development.

Progranulin (PRG), also known as granulin (GRN)-epithelin precursor (29), proepithelin, (30) or acrogranin (31), is a novel pleiotropic growth factor acting on the proliferation and development of fast-growing epithelial cells, cancer cells (32). It is also a proangiogenic factor whose expression is induced in activated endothelial cells (33) or in growing placenta (34). $\mathrm{PRG}$, recently identified as an adipokine (7), is a 68 - to $86-\mathrm{kDa}$ secreted glycoprotein which can be fragmented by some matrix metalloproteinases (MMPs) into small homologous subunits, granulins/epithelins $(35,36)$, with proinflammatory activity. Previous findings emphasize the association between PRG and type 2 diabetes as well as non-fatty liver disease, and also, its function in promoting vasodilatation (37). Some studies demonstrated the connection between PRG, vascular endothelial growth factor (VEGF) expression and the augmentation of vascular density in breast cancer $(38,39)$. VEGF is the most potent angiogenic factor for tumor development and invasion $(40,41)$ and it is secreted by adipocytes as a proangiogenic factor stimulating the migration and proliferation of endothelial cells $(23,42,43)$.

The aim of the present study was to examine the possible relationship between PRG and VEGF in adipose visceral tissue under tumorigenic or inflammatory conditions. An immunohistochemical study was conducted to quantify the expression of the aforementioned markers. In order to assess the degree of maturation and functional differentiation of the vascular network in visceral (omental) fat related to PRG and VEGF proangiogenic activity, an immunohistochemical identification of vessels with CD34, and collagen IV (Col IV) was performed.

\section{Materials and methods}

Tissue samples. Human adipose tissues were obtained after abdominal surgery for visceral pathology. The subjects were included into two groups: Group I included subjects with non-tumoral pathology (NTP) $(n=30)$ : 15 patients with inflammatory pathology (gastric ulcer, angiocolitis, peritonitis, pancreatitis) and 15 patients with obstructive mechanical pathology (hernia, eventration) and all 15 subjects of the NTP group were obese; Group II included subjects with tumoral pathology (TP): 15 patients suffering from visceral cancer (stomach, liver, ovary, gut) from which 3 were obese.

Obese patients were those with abdominal obesity ( $\varnothing>94 \mathrm{~cm}$ in men and $>80 \mathrm{~cm}$ in women) and a body mass index $(\mathrm{BMI})>30$, according to the criteria of the International Federation of Diabetes (44). BMI was calculated as weight divided by the height squared $\left(\mathrm{kg} / \mathrm{m}^{2}\right)$.

Informed consent was obtained from all the participants included in the study, which was approved by the Ethics Committee of the University of Medicine and Pharmacy of Craiova (no. 85/2019).

For each subject a fragment of omental adipose tissue was obtained and rinsed in saline solution.

Histological staining. Immediately after sampling, the tissue fragments were fixed in $10 \%$ buffered formalin for $24-48 \mathrm{~h}$ at room temperature and then processed for paraffin embedding. Sections of 3-4 $\mu \mathrm{m}$ were mounted on a glass slide and routinely stained with hematoxylin and eosin (H\&E), and trichrome Masson according to the producer's data sheet (Bio-Optica).

Immunohistochemistry. Serial sections of 3-4 $\mu \mathrm{m}$ were dewaxed and rehydrated. Antigen retrieval was performed after microwave incubation of sections in citrate buffer at pH 6.0, for $20 \mathrm{~min}$. Endogenous peroxidase was blocked after incubation with $3 \%$ hydrogen peroxide in methanol solution. After blocking, non-specific binding with 3\% skimmed milk in PBS at $\mathrm{pH}$ 7.4-7.6 for $30 \mathrm{~min}$, the sections were incubated overnight, at $4^{\circ} \mathrm{C}$, with one of the primary antibodies mentioned in Table I. Sections were then rinsed in PBS and processed for amplification of the immune signal using a detection labeling polymer [Histofine ${ }^{\circledR}$ Simple Stain ${ }^{\mathrm{TM}}$ MAX PO (MULTI) 414151 Nichirei] as mentioned in Table I. The immunostaining was detected with 3,3'-diaminobenzidine (Vector Laboratories), and finally the nuclear counterstaining was performed with Mayer's hematoxylin (Bio-Optica). Skimmed milk, the chemicals used for buffers, solvents and hydrogen peroxide were purchased from Merck.

For each antibody tested, a negative control was performed in which the primary antibody was replaced by $10 \mathrm{mM}$ PBS, $\mathrm{pH}$ 7.4-7.6.

The sections were examined and images were captured with a Nikon Eclipse 55i microscope equipped with a $5 \mathrm{Mp}$ color-cooled CCD (charge-coupled device) camera, under the Image ProPlus 7 AMS image analysis software (Media Cybernetics Inc.).

Each immunostaining section for the antibodies mentioned above was examined by two different researchers according to the following: immunohistochemical (IHC) reactions (brown deposits in labeled structures) were graded as absent (negative signal) or present (moderate or strong intensity of the signal). Images were finally processed using the Microsoft Office Picture Manager. 
Table I. Antibodies and immunohistochemical techniques used for the morphological study.

\begin{tabular}{|c|c|c|c|c|}
\hline Antibody & Dilution & Source & $\begin{array}{l}\text { Antigen } \\
\text { retrieval }\end{array}$ & $\begin{array}{l}\text { Amplification } \\
\text { method }\end{array}$ \\
\hline $\begin{array}{l}\text { Monoclonal anti-human } \\
\text { VEGF }\end{array}$ & $1: 20$ & $\begin{array}{l}\text { Thermo Fisher } \\
\text { Scientific, Inc. } \\
\text { JH121 }\end{array}$ & $\begin{array}{l}\text { Citrate buffer } \\
\text { pH } 6.0\end{array}$ & $\begin{array}{l}\text { HISTOFINE Simple } \\
\text { Stain MAX PO } \\
\text { (MULTI) } 414151 \\
\text { Nichirei }\end{array}$ \\
\hline $\begin{array}{l}\text { Monoclonal anti-human } \\
\text { collagen IV }\end{array}$ & $1: 30$ & $\begin{array}{l}\text { Dako } \\
\text { M0785 }\end{array}$ & $\begin{array}{l}\text { Citrate buffer } \\
\text { pH } 6.0\end{array}$ & $\begin{array}{l}\text { HISTOFINE Simple } \\
\text { Stain MAX PO } \\
\text { (MULTI) } 414151 \\
\text { Nichirei }\end{array}$ \\
\hline $\begin{array}{l}\text { Monoclonal anti-human } \\
\text { progranulin }\end{array}$ & $1: 20$ & $\begin{array}{l}\text { Thermo Fisher } \\
\text { Scientific, Inc. } \\
\text { 2D4-2F1 }\end{array}$ & $\begin{array}{l}\text { Citrate buffer } \\
\text { pH } 6.0\end{array}$ & $\begin{array}{l}\text { HISTOFINE Simple } \\
\text { Stain MAX PO } \\
\text { (MULTI) } 414151 \\
\text { Nichirei }\end{array}$ \\
\hline $\begin{array}{l}\text { Monoclonal anti-human } \\
\text { CD34 }\end{array}$ & $1: 50$ & $\begin{array}{l}\text { Dako } \\
\text { M7080 }\end{array}$ & $\begin{array}{l}\text { Citrate buffer } \\
\text { pH } 6.0\end{array}$ & $\begin{array}{l}\text { HISTOFINE Simple } \\
\text { Stain MAX PO } \\
\text { (MULTI) } 414151 \\
\text { Nichirei }\end{array}$ \\
\hline
\end{tabular}

\begin{abstract}
Morphometry. After general examination of the sections, for each subject and each histological or IHC-stained slide with the antibodies mentioned above, three different microscopic fields on the same section were chosen randomly in the area of interest captured with a $\mathrm{x} 20$ objective lens and examined by two different researchers. A count of the vessels marked by tagging manually on the field was performed by two researchers and the averages were used as primary values in the statistical analysis.
\end{abstract}

Statistical analysis. Statistical analysis was performed using Microsoft Excel (Microsoft Corp.), together with the XLSTAT add-on for MS Excel (Addinsoft SARL) and IBM SPSS Statistics 20.0 (IBM Corp.) for processing the data. Data were recorded using Microsoft Excel files, then the data were statistically analyzed to determine the relationship between histological parameters of the patients. A descriptive analysis of the study group (percentages of cases for categorical date, mean and standard deviation for numerical data) and complex statistical tests (Chi square and Fisher's exact test, Student's t-test) were performed using the abovementioned statistical software.

To test the normality of the data for the parameters involved in this study (number of blood vessels counted using different histological markers) the Anderson-Darling test was used. As the numerical variables investigated had a normal distribution of data, globally or inside each studied group, parametric statistical tests such as the Student's t-test were employed and the results are summarized as the mean value \pm standard deviation. $\mathrm{P}<0.05$ was considered to indicate a statistically significant difference.

Using the Pearson's ' $r$ ' correlation coefficient for two normally distributed data sets (or linear correlation coefficient), which measures the degree of relationship between two variables, the relationship between PRG and VEGF for the two groups of patients was analyzed. The small number of obese subjects in the TP group prevented us from performing a statistically significant correlation between lean and obese subjects for all the markers.

\section{Results}

Hematoxylin and eosin or trichrome staining. Histological staining with hematoxylin and eosin or trichrome showed the characteristic distribution of adipose cells in the adipose lobules. In the samples from the obese subjects a pronounced heterogeneity of adipose cell dimension was observed (Fig. 1A).

The Student's t-test did not reveal any significant difference between patients with mechanical or inflammatory pathology and those with tumor pathology, in terms of the number of capillaries identified by trichrome or hematoxylin and eosin staining $(\mathrm{P}=0.0787)$ (Table II).

Each lobule contained some middle vessels (arterioles or venules) and many very small capillaries (new capillaries) around the adipose cells (Fig. 1A). All these vessels were consistently marked with CD34 in inflammatory and in tumoral pathology (Fig. 1B and K) and inconsistently with PRG (Fig. 1C) and Col IV (Fig. 1E and F). In both groups, proinflammatory cells were noted inside the vessel lumen, perivascular and in the SVF between the adipose cells. In visceral adipose tissue from the TP group, these stromal cells were largely positive for PRG and CD34 (Fig. 1H, I and L).

The result of the Student's t-test revealed a significant difference $(\mathrm{P}=0.0106)$ between patients with mechanical and inflammatory pathology (NTP) and those with tumor pathology (TP) in terms of the number of capillaries identified by labeling them for PRG (Table III).

There was no significant difference between the number of blood vessels identified in normal-weight and obese patients, 
A

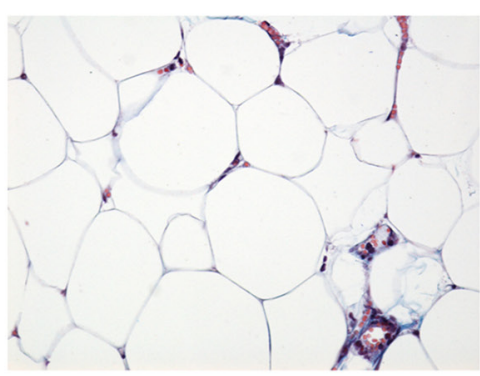

Trichrome

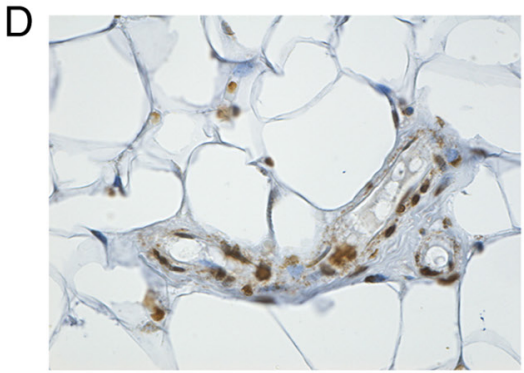

VEGF

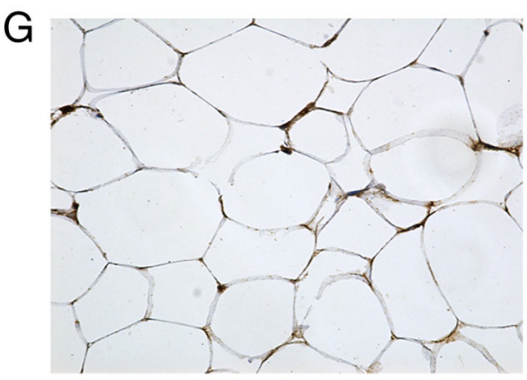

VEGF

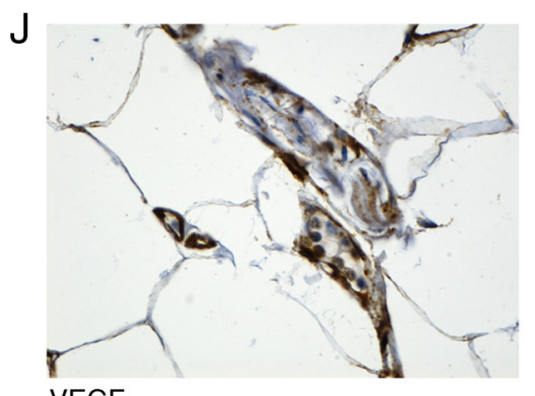

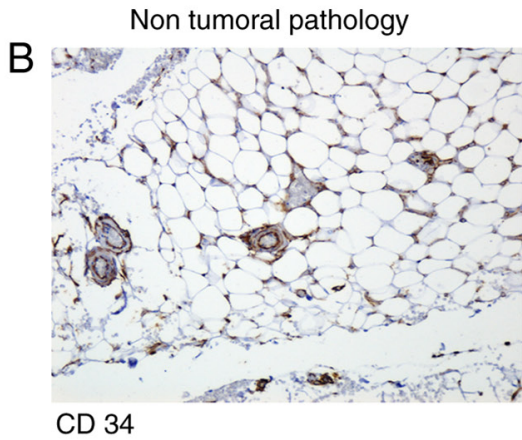

\section{E}

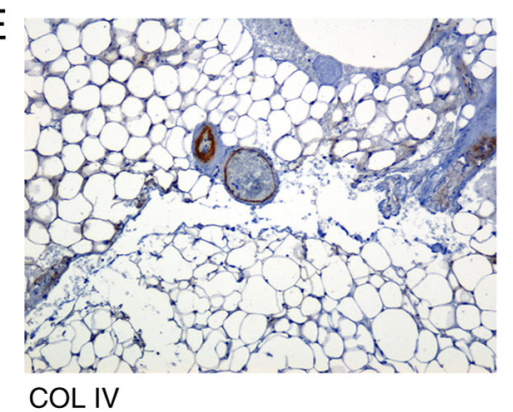

$\mathrm{H}$

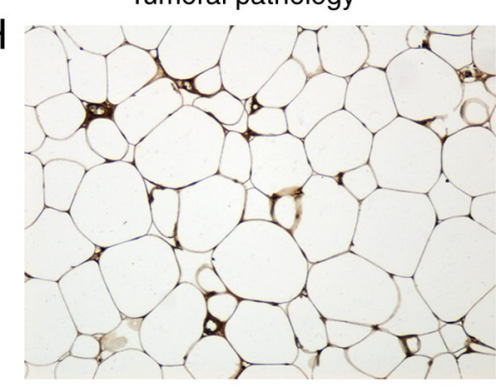

Progranulin

$\mathrm{K}$

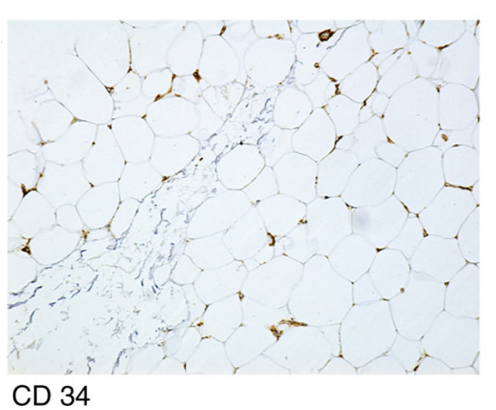

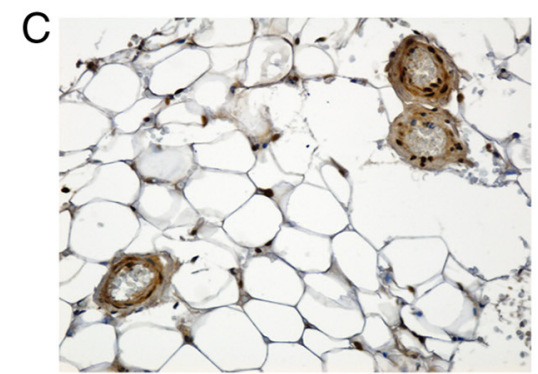

Progranulin

F
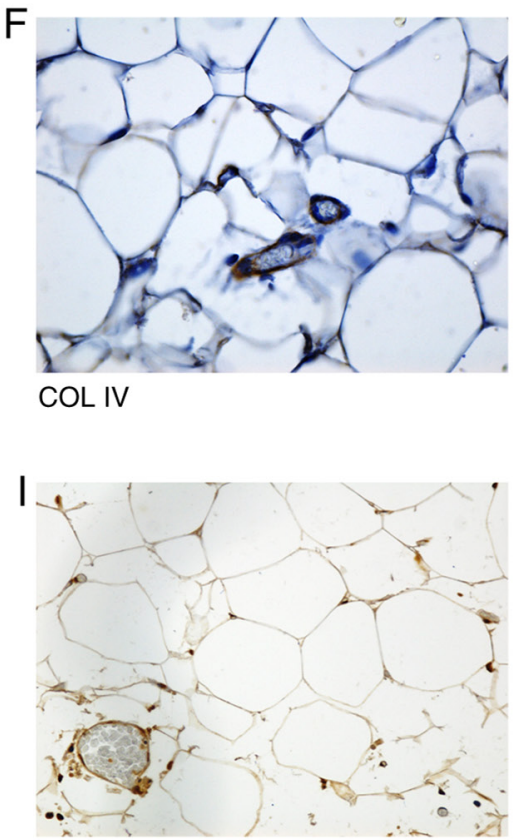

Progranulin

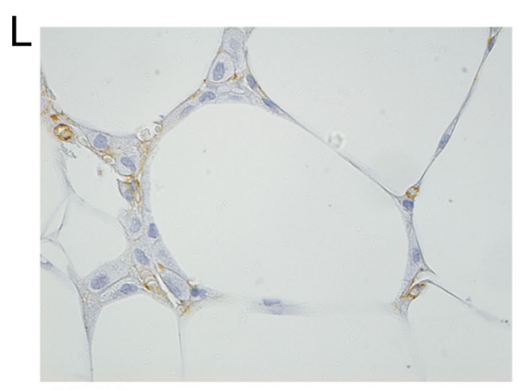

CD 34

Figure 1. Microscopic aspects of the adipose tissue sections from patients with non-tumoral pathology (NTP) group and tumoral pathology (TP) group. Microscopic aspects of the adipose tissue sections from patients with non-tumoral pathology (NTP) group (A-F): (A) Trichrome. Adipose tissue from epiploon, inflammatory cells were present in vessels and in stromo-vascular fraction (SVF), intermingled with the adipocytes. Magnification, x400. (B) CD34. General view of an adipose lobule: double positive concentric rings are noted around the vessels. Magnification, x100. (C) PRG. Positive cells for PRG in vessels and in SVF. Magnification, x20. (D) VEGF. Endothelial positivity for VEGF in SVF cells and in endothelial cells. Magnification, x40. (E) Col IV. General aspect of an adipose pad, vessels on the periphery are positive for Col IV. Magnification, x45. (F) Col IV. Few capillaries inside of the adipose lobule immunolabeled with Col IV. Magnification, x400. (G-L) Microscopic aspects of the adipose tissue sections from patients with tumoral pathology (TP group): (G) VEGF was positive in endothelial cells and in mature adipocytes. Magnification, $\mathrm{x} 400 .(\mathrm{H})$ Adipose cells and capillaries with intense reaction for PRG. Magnification, x200. (I) PRG intense positive reaction in vessels. Magnification, $x 400$. (J) VEGF. Positive reaction in vessels walls. Magnification, x400. (K) CD34. Numerous vessels positive for CD34. Magnification, x100. (L) CD34. New forming vessels and stromal cells positive for CD34. Magnification, x400. SVF, stromo-vascular fraction; PRG, progranulin; VEGF, vascular endothelial growth factor; Col IV, collagen IV.

not for inflammatory and mechanical pathologies, nor for tumoral pathologies.

Number of capillaries. CD34 and PRG immune reaction showed a stronger positivity deep in the lobule than in the peripheral area and PRG was constantly present in endothelial cells of the very small neoformation capillaries (Fig. 1H and I). In adipose tissue samples collected from patients of the TP group, the adipose cells also showed a positive reaction for PRG (Fig. 1H and I). In the medium vessels, CD34-positive 
Table II. Number of capillaries identified with usual histological staining.

\begin{tabular}{lcc}
\hline $\begin{array}{l}\text { Pathology vs. } \\
\text { Trichrome/H\&E }\end{array}$ & $\begin{array}{c}\text { Non-tumoral } \\
\text { pathology }\end{array}$ & $\begin{array}{c}\text { Tumoral } \\
\text { pathology }\end{array}$ \\
\hline No. of cases & 30 & 15 \\
Mean & 28.23 & 32.47 \\
SD & 8.16 & 5.64 \\
C.V. (\%) & $28.89 \%$ & $17.38 \%$ \\
P-value & 0.0787 & $\mathrm{NS}$ \\
(Student's t-test) & & \\
\hline
\end{tabular}

SD, standard deviation; H\&E, hematoxylin and eosin; C.V., coefficient of variation; NS, not significant.

Table III. Number of capillaries labeled with progranulin (PRG).

\begin{tabular}{lcc}
\hline $\begin{array}{l}\text { Pathology vs. } \\
\text { PRG }\end{array}$ & $\begin{array}{c}\text { Non-tumoral } \\
\text { pathology }\end{array}$ & $\begin{array}{c}\text { Tumoral } \\
\text { pathology }\end{array}$ \\
\hline No. of cases & 30 & 15 \\
Mean & 16.17 & 22.53 \\
SD & 7.00 & 8.53 \\
C.V. (\%) & $43.29 \%$ & $37.88 \%$ \\
P-value & 0.0106 & $\mathrm{NS}$ \\
(Student's t-test) & & \\
\hline
\end{tabular}

SD, standard deviation; C.V., coefficient of variation; NS, not significant.

cells formed a double circular layer in the endothelium and in the adventitial lamina (Fig. 1B).

Following the Student's t-test it was found that there was a high significant difference of the number of capillaries labeled for CD34 ( $\mathrm{P}=0.0006)$ between patients with mechanical or inflammatory pathology and those with tumor pathology (Table IV).

VEGF displayed an inconstant positivity in the capillaries from the NTP group, being also present in some proinflammatory cells (Fig. 1D). Additionally, in the TP group all the vessels, medium and new capillaries and proinflammatory cells were positive for VEGF (Fig. 1J). By contrast, adipocytes from the NTP group (Fig. 1D) and more frequently small adipocytes from the TP group (Fig. 1G) showed positivity for VEGF.

The Student's t-test did not reveal a significant difference between the number of blood vessels identified in normal-weight and obese patients for the NTP group $(\mathrm{P}=0.242)$ but we found significant differences for the number of blood vessels in normal-weight and obese patients in TP group $(\mathrm{P}=0.017)$ (Table V).

After performing the Student's t-test, a significant difference of the number of Col IV-positive capillaries between patients with mechanical or inflammatory pathology, i.e., NTP group and those with tumor pathology was observed $(\mathrm{P}=0.0217)$
Table IV. Number of capillaries labeled with CD34.

\begin{tabular}{lcc}
\hline $\begin{array}{l}\text { Pathology vs. } \\
\text { CD34 }\end{array}$ & $\begin{array}{c}\text { Non-tumoral } \\
\text { pathology }\end{array}$ & $\begin{array}{c}\text { Tumoral } \\
\text { pathology }\end{array}$ \\
\hline No. of cases & 30 & 15 \\
Mean & 21.63 & 31.93 \\
SD & 9.39 & 7.60 \\
C.V. (\%) & $43.42 \%$ & $23.80 \%$ \\
P-value & 0.0006 & $\mathrm{HS}$ \\
(Student's t-test) & & \\
\hline
\end{tabular}

SD, standard deviation; C.V., coefficient of variation; HS, highly significant.

(Table VI). Any significant difference was noted between the number of blood vessels identified in normal-weight and obese patients neither for inflammatory and mechanical pathologies nor for tumoral pathologies.

Finally, the relationship between PRG and VEGF for the two groups of patients, NTP with inflammatory and mechanical pathology, and TP with tumoral pathology, was examined. For the first group, the Pearson correlation coefficient was $\mathrm{r}=0.595$, showing a statistically significant direct correlation, with a significance level of $95 \%$ for 30 samples $(\mathrm{P}<0.05)$. For the second group, the Pearson correlation coefficient was $\mathrm{r}=-0.378$, showing an inverse correlation, without having a statistical significance for a group of 15 samples (Fig. 2).

\section{Discussion}

The development of a newly formed network of blood vessels through the secretion of angiogenetic factors is a common attribute of tumor growth and adipose tissue expanding in the case of a high caloric regime. In both circumstances, the rapid growth of blood vessels is stimulated by various tumorigenic-secreted molecules or adipokines synthetized in excess of caloric intake.

The results provided in the present study sustain the direct suggestion of progranulin (PRG) as an angiogenetic factor in omental adipose tissue in subjects developing abdominal tumors and we compared the proangiogenic activity of PRG and VEGF in visceral pads under inflammatory and tumoral conditions.

The results of the present study demonstrated that the number of vessels positively marked with PRG was significantly higher in the TP group than that noted in the inflammatory pathology group (NTP). However, no significant difference was observed between the lean and obese patients, for the inflammatory and mechanical pathologies, nor for the tumoral pathologies. The results may be due to the small number of obese patients included in the tumoral pathology (TP) group; on the other hand, two patients from this group declared during the medical history dialog that they had lost weight up until the time of the surgery; thus, it may be possible that they were obese at the onset of the pathology. Youn et al obtained similar results for the visceral adipose tissue from obese subjects, demonstrating that the adipocytes and the 
Table V. Comparison between the number of vessels labeled for VEGF between lean and obese patients.

\begin{tabular}{|c|c|c|c|c|}
\hline \multirow{2}{*}{$\begin{array}{l}\text { Pathology } \\
\text { Weight }\end{array}$} & \multicolumn{2}{|c|}{ Non-tumoral pathology } & \multicolumn{2}{|c|}{ Tumoral pathology } \\
\hline & Normal weight & Obese & Normal weight & Obese \\
\hline No of cases & 15 & 15 & 12 & 3 \\
\hline Mean & 20.27 & 16.07 & 25.00 & 17.67 \\
\hline $\mathrm{SD}$ & 11.07 & 7.91 & 4.22 & 3.79 \\
\hline C.V. $(\%)$ & $54.64 \%$ & $49.26 \%$ & $16.88 \%$ & $21.43 \%$ \\
\hline $\begin{array}{l}\text { P-value } \\
\text { (Student's t-test) }\end{array}$ & \multicolumn{2}{|c|}{$0.242(\mathrm{NS})$} & \multicolumn{2}{|c|}{$0.017(\mathrm{~S})$} \\
\hline
\end{tabular}

SD, standard deviation; CV, coefficient of variation; NS, not significant; S, significant.

Table VI. Number of capillaries labeled for collagen IV.

\begin{tabular}{lcc}
\hline $\begin{array}{l}\text { Pathology vs. } \\
\text { Collagen IV }\end{array}$ & $\begin{array}{c}\text { Non-tumoral } \\
\text { pathology }\end{array}$ & $\begin{array}{c}\text { Tumoral } \\
\text { pathology }\end{array}$ \\
\hline No. of cases & 30 & 15 \\
Mean & 22.83 & 17.80 \\
SD & 7.55 & 4.36 \\
C.V. (\%) & $33.08 \%$ & $24.51 \%$ \\
P-value & 0.0217 & $\mathrm{~S}$ \\
(Student's t-test) & &
\end{tabular}

$\mathrm{SD}$, standard deviation; CV, coefficient of variation; NS, not significant; S, significant.

cells from the SVF contribute to PRG expression in adipose tissue (45). Correlating these results with the serum level of PRG authors of that study suggested that PRG contributes to the crosstalk between macrophages and adipocytes in the adipose tissue and could be one of the molecules involved in the increase of the macrophage number in the visceral adipose tissue of obese subjects.

PRG is less expressed in quiescent vessels and more intensely in tissue with active angiogenesis: in normal tissues (developing placenta or wound healing) $(33,34)$ or tumoral diseases (46-48). The results of the present study demonstrated that the vessels marked with PRG were more numerous in the adipose pads of the tumoral milieu than in the inflammatory ones, and the positivity observed from the IHC reaction was not restricted to vessels, but was expressed also in adipocytes and migrated cells. Thus, PRG overexpression in the vessel walls and equally in adipocytes and stromal cells may be induced by proangiogenic molecules synthetized by the neighboring tumor.

The angiogenic action of PRG seems to be performed at least under certain circumstances (such as in breast cancer and breast cancer cell lines) (39) under the influence of the main proangiogenic factor, VEGF. In order to assess the collaboration between the two molecules, we performed an IHC study for the expression of VEGF in blood vessels of the same lots. A significant difference between patients with mechanical and inflammatory pathology (NTP) and those with tumor pathology (TP) in terms of the number of capillaries identified, similar to PRG, was not evident. However, VEGF expression showed a significant difference between lean and obese subjects in the TP group. This aspect may be explained by the canonical model of vascular development whereby the oncogenic vascularization and the vascular network in adipose pads are both induced by the rapid growth of the tissue and the onset of hypoxic conditions, with an increase in VEGF expression (49).

As observed in the IHC reactions for PRG and VEGF, not only the capillaries demonstrate an immune positivity for the two molecules, but also the adipocytes and cells from the stromal tissue. Similar results were reported by others showing that both SVF and mature adipocytes express $\operatorname{VEGF}(24,50)$.

In obese subjects, when the blood supply becomes deficient, as in all fast-growing tissues, the whole human adult adipose tissue can induce angiogenesis from its own cells, adipocytes or stromal cells, or can recruit distant endothelial cells (24). In human and animal models, it was demonstrated that VEGF is produced by adult adipocytes and stromovascular cells $(2,51)$. Corroborating our results with findings by others $(24,52)$, an interesting hypothesis to understand the adaptation of the vascular network density to the adipose pads volume was that the synthesis of adipogenic factors is related to the variation of weight rather than to the absolute weight. Our results demonstrated that weight may influence the expression of VEGF in tumoral pathology but not in inflammatory or mechanical diseases, and that weight does not seem to have the same influence for PRG expression.

The present study was carried out on a small number of cases, and must therefore be considered a pilot study. Research on a larger group of patients should be conducted to perform a comparison with significant results between VEGF and PRG in lean and obese subjects.

When and how locally secreted PRG and VEGF could influence individually or by molecular crosstalk the initiation and the development of visceral tumors is a controversial subject. It is often emphasized that the tumor microenvironment provides angiogenetic factors released by the tumor cells or by the stromal cells surrounding the tumors $(20,53)$. VEGF, leptin and recently described PRG are similarly expressed 


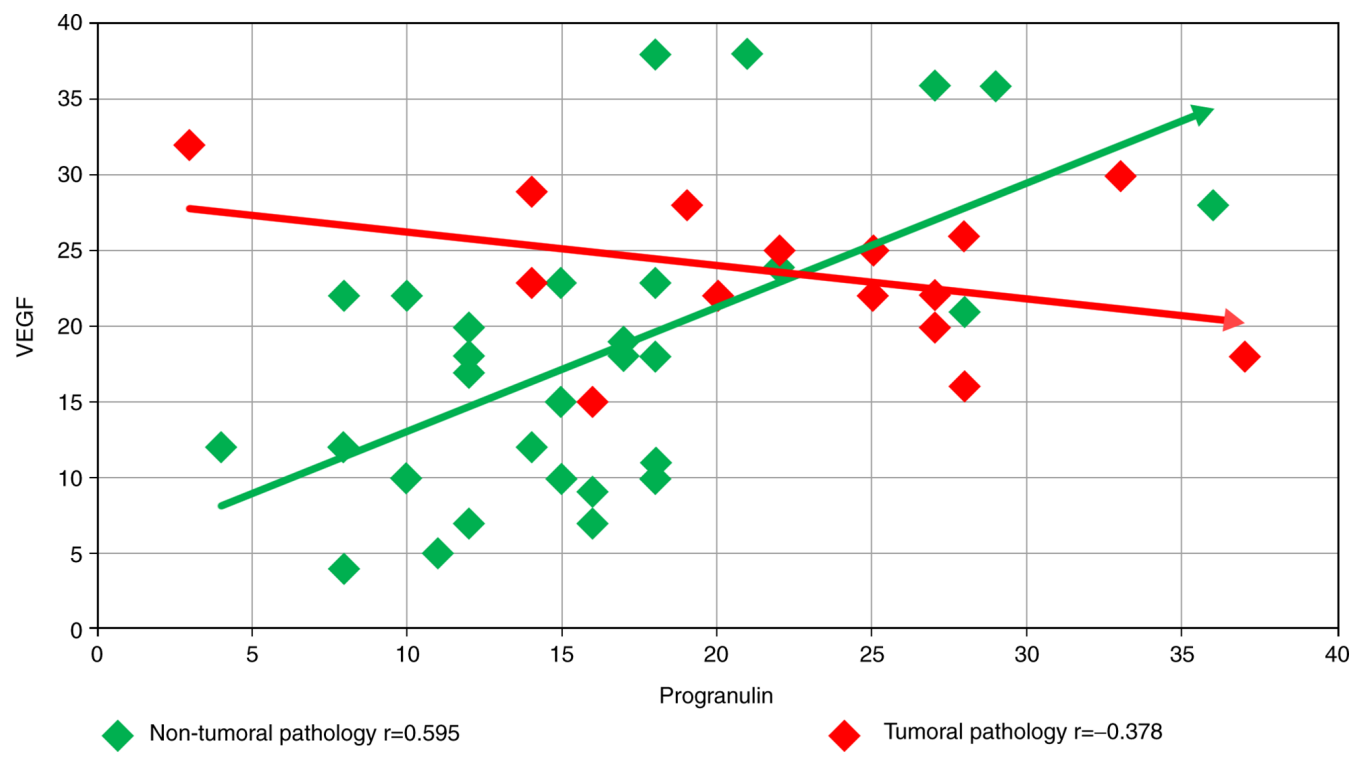

Figure 2. Correlation between PRG and VEGF expression. PRG, progranulin; VEGF, vascular endothelial growth factor.

in adipose tissue and the tumoral vascular network development $(25,50,54-56)$. Overexpression of PRG was reported in renal, breast or ovarian cancers (57-59), organs embedded in an active metabolic adipose tissue. Tangkeangsirisin et al demonstrated that PRG could promote tumor angiogenesis and metastasis in human breast cancer by stimulating the synthesis of VEGF and MMP9 (39).

In a mouse developmental model, Toh et al demonstrated that the expression of VEGF and its receptors is compulsory for early vasculogenesis in embryo, but PRG was expressed later, its synthesis being instead necessary for vessel growth and stability and may represent a novel angiogenic pathway (48). The results reported by Tangkeangsirisin and Serrero for breast tumors support the hypothesis that the increased VEGF expression was determined rather than an indirect effect of stromal cells found in the tumor environment by the PRG direct stimulation of VEGF expression (39).

The statistical correlations between the two angiogenetic factors analyzed in our experiment showed interesting differences. As shown in Fig. 2, for the first group (NTP), the Pearson correlation coefficient showed a statistically significant direct correlation $(r=0.595)$, while for the second smaller group (TP), the Pearson coefficient showed an inverse correlation, without having any statistical significance $(\mathrm{r}=-0.378)$. The results may indicate that the angiogenetic factors are simultaneously present stimulating vessel formation in inflammatory conditions, or in different steps, thereby correlating our results with the influence of VEGF on PRG synthesis as emphasized by Toh et al in the experimental model (48). An interesting question is whether the duration of evolution of the disease which induces blood vessel formation is important for the concomitance or the individuality action of the angiogenetic factors.

The angiogenesis process includes several chronological steps; in sprouting angiogenesis, the endothelial cells break down the existing basal membrane, and during the last step the formation of the basal membrane (of which the type IV collagen is a main component) by the newly formed endothelial cells and probably by the pericytes occurs $(60,61)$. Col IV is the main constituent of the lamina densa of the basal membrane, secreted by the endothelial cells and pericytes in the final step of the sequential angiogenic process (61) and required for blood vessel maturation and homeostasis (62).

In order to assess the incidence of mature capillaries in the two lots of subjects we performed an IHC study using the Col IV antibody. The results showed a significant difference between patients with mechanical and inflammatory pathology (NTP group and those with TP), in terms of the number of capillaries identified. In the TP group, few vessels were labeled inside the adipose lobules, and those located superficially and the small new forming vessels were inconstantly positive. Considering Col IV as a marker for mature functional vascular wall, we may affirm that in the adipose tissue of the TP group, PRG stimulates the formation of newly less mature and functional vessels, lacking a basal membrane. Considering this observation, we supposed that a proportion of the remaining hidden capillaries may be newly formed. We used CD34, a major endothelial cell marker present on hematopoietic stem cells and on progenitor cells (63), in order to label these presumed capillaries. In terms of the number of capillaries identified, a highly significant difference $(\mathrm{P}<0.001)$ between patients with mechanical or inflammatory pathology and those with tumor pathology was found.

Stromal vascular fraction of adipose pads contains a population of CD34-positive cells, identified as adipose tissue-derived stem cells (ADSC), considered adult stem cells which reside in a perivascular location (64-66). Our results are in accordance with those of Zannettino et al as we observed the abundance of CD34-positive cells inside the adipose lobules, in endothelial or stromal cells (67). In that study, it was found that mesenchymal cells including adipose stem cells are resident in perivascular niches. The double circle of CD34-positive cells that authors of the present study and Lin et al (65) observed around the lumen of the arterioles and venules is described as being formed by endothelial cells in the inner circle and adventitial CD $34^{+} \mathrm{CD} 31$ cells in the outer one. In aortic adventitia, this population was described as vascular progenitor cells (68). 
Considering these results together with the significant number of vessels marked by PRG in the TP group, we were able to sustain that in the PRG omental adipose pads had a significant contribution to induce angiogenesis in a tumoral ambience, and that this capacity is complementary with VEGF action in NTP.

In summary, PRG is an adipokine able to act as an effective proangiogenic factor in visceral adipose tissue, with the formation of new capillaries in visceral tumors. However, whether the angiogenic response to PRG synthesis is influenced or not by inflammation and obesity remains to be determined.

VEGF is more efficient in stimulating the formation of new vessels in inflammatory conditions depending on weight. The collaboration of the proangiogenic activity of PRG and VEGF in the adipose tissue under tumor conditions may be dependent on the visceral tumor type.

\section{Acknowledgements}

We are thankful for the technical support provided by Cristina Stănciucă from the Histology Department, University of Medicine and Pharmacy of Craiova, Romania.

\section{Funding}

No funding was received.

\section{Availability of data and materials}

The datasets used and/or analyzed during the current study are available from the corresponding author on reasonable request.

\section{Authors' contributions}

IB, MCM, DA and SJ made equal contributions to the conception and editing of this manuscript. IB, IMB, MCM, $\mathrm{SJ}$ and CGP were involved in literature research and wrote the manuscript. Data curation was performed by IB, IMB and CGP. DA supported the statistical analysis and reviewed the results. IB, IMB, SJ and CGP conceived, planned and followed the execution of the experiments. AMA, MCM and IMB performed morphometry. All authors contributed to manuscript revision, read and approved the final version. AMA, MCM, IB, IMB, SJ and CGP are all responsible for the authenticity of the data obtained.

\section{Ethics approval and consent to participate}

The study was approved by The Ethics Committee of The University of Medicine and Pharmacy of Craiova, Romania (approval no. 85/2019). All patients included in the study provided informed consent for data publication.

\section{Patient consent for publication}

Not applicable.

\section{Competing interests}

The authors declare that they have no competing interests.

\section{Authors' information}

This study is part of the Ph.D. thesis of Ioana Binisor, from the University of Medicine and Pharmacy of Craiova, Romania.

\section{References}

1. Divella R, De Luca R, Abbate I, Naglieri E and Daniele A: Obesity and cancer: The role of adipose tissue and adipo-cytokines-induced chronic inflammation. J Cancer 7: 2346-2359, 2016.

2. Marlatt KL and Ravussin E: Brown adipose tissue: An update on recent findings. Curr Obes Rep 6: 389-396, 2017.

3. Yoneshiro T, Aita S, Matsushita M, Kayahara T, Kameya T, Kawai Y, Iwanaga T and Saito M: Recruited brown adipose tissue as an antiobesity agent in humans. J Clin Invest 123: 3404-3408, 2013.

4. Andrei AM, Berbecaru-Iovan A, Din-Anghel FRI, Stănciulescu CE, Berbecaru-Iovan S, Baniţă IM and Pisoschi CG: Chapter 16. Interplay between hypoxia, inflammation and adipocyte remodeling in the metabolic syndrome. In: Hypoxia and Human Diseases. Zheng J (ed). IntechOpen, pp303-329, 2017.

5. Andrei AM, Berbecaru-Iovan A, Din-Anghel FRI, Binisor ID, Marinescu RM, Goga LD, Baniță IM and Pisoschi CG: New insights into brown adipose tissue as a pharmacological target in obesity. Farmacia 68: 1-7, 2020.

6. Fusaru AM, Stănciulescu CE, Surlin V, Taisescu C, Bold A, Pop OT, Baniţă IM, Crăiţoiu S and Pisoschi CG: Role of innate immune receptors TLR2 and TLR4 as mediators of the inflammatory reaction in human visceral adipose tissue. Rom J Morphol Embryol 53 (3 Suppl): 693-701, 2012.

7. Francisco V, Pino J,Gonzalez-Gay MA, Mera A, Lago F, Gómez R, Mobasheri A and Gualillo O: Adipokines and inflammation: Is it a question of weight? Br J Pharmacol 175: 1569-1579, 2018.

8. Schäffler A and Schölmerich J: Innate immunity and adipose tissue biology. Trends Immunol 31: 228-235, 2010.

9. Hotamisligil GS: Inflammation and metabolic disorders. Nature 444: 860-867, 2006

10. Cozzo AJ, Fuller AM and Makowski L: Contribution of adipose tissue to development of cancer. Compr Physiol 8: 237-282, 2017.

11. Venniyoor A: The most important questions in cancer research and clinical oncology-question 2-5. Obesity-related cancers: More questions than answers. Chin J Cancer 36: 18, 2017.

12. Mendonça F and Soares R: Obesity and cancer phenotype: Is angiogenesis a missed link? Life Sci 139: 16-23, 2015.

13. Booth AD, Magnuson AM, Fouts J, Wei Y, Wang D, Pagliassotti MJ and Foster MT: Subcutaneous adipose tissue accumulation protects systemic glucose tolerance and muscle metabolism. Adipocyte 7: 261-272, 2018.

14. Arnold M, Pandeya N, Byrnes G, Renehan PAG, Stevens GA, Ezzati PM, Ferlay J, Miranda JJ, Romieu I, Dikshit R, et al: Global burden of cancer attributable to high body-mass index in 2012: A population-based study. Lancet Oncol 16: 36-46, 2015.

15. Lauby-Secretan BP, Scoccianti C, Loomis D, Grosse Y, Bianchini F and Straif K; International Agency for Research on Cancer Handbook Working Group: Body fatness and cancer-viewpoint of the IARC working group. N Engl J Med 375: 794-798, 2016.

16. Pollak M: The insulin and insulin-like growth factor receptor family in neoplasia: An update. Nat Rev Cancer 12: 159-169, 2012.

17. Colotta F, Allavena P, Sica A, Garlanda C and Mantovani A: Cancer-related inflammation, the seventh hallmark of cancer: Links to genetic instability. Carcinogenesis 30: 1073-1081, 2009.

18. Khandekar MJ, Cohen P and Spiegelman BM: Molecular mechanisms of cancer development in obesity. Nat Rev Cancer 11: 886-895, 2011.

19. Nieman KM, Kenny HA, Penicka CV, Ladanyi A, Buell-Gutbrod R, Zillhardt MR, Romero IL, Carey MS, Mills GB, Hotamisligil GS, et al: Adipocytes promote ovarian cancer metastasis and provide energy for rapid tumor growth. Nat Med 17: 1498-1503,2011.

20. Nieman KM, Romero IL, Van Houten B and Lengyel E: Adipose tissue and adipocytes support tumorigenesis and metastasis. Biochim Biophys Acta 1831: 1533-1541, 2013.

21. Rehman J, Traktuev D, Li J, Merfeld-Clauss S, Temm-Grove CJ, Bovenkerk JE, Pell CL, Johnstone BH, Considine RV and March KL: Secretion of angiogenic and antiapoptotic factors by human adipose stromal cells. Circulation 109: 1292-1298, 2004.

22. Halberg N, Wernstedt-Asterholm I and Scherer PE: The adipocyte as an endocrine cell. Endocrinol Metab Clin North Am 37: 753-768, 2008.

23. Christiaens V and Lijnen HR: Angiogenesis and development of adipose tissue. Mol Cell Endocrinol 318: 2-9, 2010. 
24. Ledoux S, Queguiner I, Msika S, Calderari S, Rufat P, Gasc JM Corvol P and Larger E: Angiogenesis associated with visceral and subcutaneous adipose tissue in severe human obesity. Diabetes 57: 3247-3257, 2008.

25. Sun K, Kusminski CM and Scherer PE: Adipose tissue remodeling and obesity. J Clin Invest 121: 2094-2101, 2011.

26. Cao Y: Angiogenesis and vascular functions in modulation of obesity, adipose metabolism, and insulin sensitivity. Cell Metab 18: 478-489, 2013

27. Lijnen HR: Angiogenesis and obesity. Cardiovasc Res 78 286-293, 2008

28. Hammarstedt A, Gogg S, Hedjazifar S, Nerstedt A and Smith U: Impaired adipogenesis and dysfunctional adipose tissue in human hypertrophic obesity. Physiol Rev 98: 1911-1941, 2018.

29. Zanocco-Marani T, Bateman A, Romano G, Valentinis B, He ZH and Baserga R: Biological activities and signaling pathways of the granulin/epithelin precursor. Cancer Res 59: 5331-5340, 1999

30. Shoyab M, McDonald VL, Byles C, Todaro GJ and Plowman GD: Epithelins 1 and 2: Isolation and characterization of two cysteine-rich growth-modulating proteins. Proc Natl Acad Sc USA 87: 7912-7916, 1990.

31. Anakwe OO and Gerton GL: Acrosome biogenesis begins during meiosis: Evidence from the synthesis and distribution of an acrosomal glycoprotein, acrogranin, during guinea pig spermatogenesis. Biol Reprod 42: 317-328, 1990

32. Jian J, Konopka J and Liu C: Insights into the role of progranulin in immunity, infection, and inflammation. J Leukoc Biol 93: 199-208, 2013.

33. He Z, Ong CH, Halper J and Bateman A: Progranulin is a mediator of the wound response. Nat Med 9: 225-229, 2003.

34. Desmarais J, Cao M, Bateman A and Murphy B: Spatiotemporal expression pattern of progranulin in embryo implantation and placenta formation suggests a role in cell proliferation, remodeling, and angiogenesis. Reproduction 136: 247-257, 2008.

35. Jian J, Li G, Hettinghouse A and Liu C: Progranulin: A key player in autoimmune diseases. Cytokine 101: 48-55, 2018

36. Wei J, Hettinghouse A and Liu C: The role of progranulin in arthritis. Ann NY Acad Sci 1383: 5-20, 2016.

37. Korolczuk A and Bełtowski J: Progranulin, a new adipokine at the crossroads of metabolic syndrome, diabetes, dyslipidemia and hypertension. Curr Pharm Des 23: 1533-1539, 2017.

38. Li LQ, Min LS, Jiang Q, Ping JL, Li J and Dai LC: Progranulin expression in breast cancer with different intrinsic subtypes. Pathol Res Pract 208: 210-216, 2012

39. Tangkeangsirisin $\mathrm{W}$ and Serrero G: PC cell-derived growth factor (PCDGF/GP88, progranulin) stimulates migration, invasiveness and VEGF expression in breast cancer cells. Carcinogenesis 25 $1587-1592,2004$

40. Ferrara N: Vascular endothelial growth factor: Basic science and clinical progress. Endocr Rev 25: 581-611, 2004

41. Tammela T, Enholm B, Alitalo K and Paavonen K: The biology of vascular endothelial growth factors. Cardiovasc Res 65 : 550-563, 2005 .

42. Ikeda K: Adipose tissue angiogenesis: An emerging therapeutic target for obesity and methabolic disease. Austin J Clin Cardiolog 1: 1005, 2014.

43. Lemoine AY, Ledoux S and Larger E: Adipose tissue angiogenesis in obesity. Thromb Haemost 110: 661-668, 2013.

44. Alberti KG, Eckel RH, Grundy SM, Zimmet PZ, Cleeman JI, Donato KA, Fruchart JC, James WP, Loria CM, Smith SC Jr, et al: Harmonizing the metabolic syndrome. A joint interim statement of the international diabetes federation task force on epidemiology and prevention; national heart, lung, and blood institute American heart association; world heart federation; international atherosclerosis society; and international association for the study of obesity. Circulation 120: 1640-1645, 2009.

45. Youn BS, Bang SI, Klöting N, Park JW, Lee N, Oh JE, Pi KB, Lee TH, Ruschke K, Fasshauer M, et al: Serum progranulin concentrations may be associated with macrophage infiltration into omental adipose tissue. Diabetes 58: 627-636, 2009.

46. Davidson B, Alejandro E, Flørenes VA, Goderstad JM, Risberg B, Kristensen GB, Trope CG and Kohn EC: Granulin-epithelin precursor is a novel prognostic marker in epithelial ovarian carcinoma. Cancer 100: 2139-2147, 2004

47. Gonzalez EM, Mongiat M, Slater SJ, Baffa R and Iozzo RV A novel interaction between perlecan protein core and progranulin: Potential effects on tumor growth. J Biol Chem 278 38113-38116, 2003.

48. Toh H, Cao M, Daniels E and Bateman A: Expression of the growth factor progranulin in endothelial cells influences growth and development of blood vessels: A novel mouse model. PLoS One 8: e64989, 2013.
49. Corvera S and Gealekman O: Adipose tissue angiogenesis: Impact on obesity and type-2 diabetes. Biochim Biophys Acta 1842: 463-472, 2014

50. Zhang QX, Magovern CJ, Mack CA, Budenbender KT, Ko W and Rosengart TK: Vascular endothelial growth factor is the major angiogenic factor in omentum: Mechanism of the omentum-mediated angiogenesis. J Surg Res 67: 147-154, 1997.

51. Fusaru AM, Pisoschi CG, Bold A, Taisescu C, Stănescu R, Hîncu M, Crăiţoiu S and Baniţă IM: Hypoxia induced VEGF synthesis in visceral adipose depots of obese diabetic patients. Rom J Morphol Embryol 53: 903-909, 2012.

52. Voros G, Maquoi E, Demeulemeester D, Clerx N, Collen D and Lijnen HR: Modulation of angiogenesis during adipose tissue development in murine models of obesity. Endocrinology 146: 4545-4554, 2005.

53. Folkman J: Role of angiogenesis in tumor growth and metastasis. Semin Oncol 29 (Suppl 16): S15-S18, 2002.

54. Hicklin DJ and Ellis LM: Role of the vascular endothelial growth factor pathway in tumor growth and angiogenesis. J Clin Oncol 23: 1011-1027, 2005.

55. Papetti M and Herman IM: Mechanisms of normal and tumor-derived angiogenesis. Am J Physiol Cell Physiol 282: C947-C970, 2002

56. Gonzalez-Perez RR, Lanier V and Newman G: Leptin's pro-angiogenic signature in breast cancer. Cancers (Basel) 5: 1140-1162, 2013.

57. Lu R and Serrero G: Inhibition of PC cell-derived growth factor (PCDGF, epithelin/granulin precursor) expression by antisense PCDGF cDNA transfection inhibits tumorigenicity of the human breast carcinoma cell line MDA-MB-468. Proc Natl Acad Sci USA 97: 3993-3998, 2000.

58. Donald CD, Laddu A, Chandham P, Lim SD, Cohen C, Amin M, Gerton GL, Marshall FF and Petros JA: Expression of progranulin and the epithelin/granulin precursor acrogranin correlates with neoplastic state in renal epithelium. Anticancer Res 21: 3739-3742, 2001

59. Jones MB, Michener CM, Blanchette JO, Kuznetsov VA, Raffeld M, Serrero G, Emmert-Buck MR, Petricoin EF, Krizman DB, Liotta LA and Kohn EC: The granulin-epithelin precursor/PC-cell-derived growth factor is a growth factor for epithelial ovarian cancer. Clin Cancer Res 9: 44-51, 2003.

60. Sand JMB, Genovese F, Gudmann NS and Karsdal MA: Chapter 4-type IV collagen. In: Biochemistry of Collagens, Laminins and Elastin. Karsdal MA (ed). 2nd edition. Academic Press, pp37-49, 2019.

61. Maragoudakis ME: The role of basement membrane in angiogenesis. In: Vascular Endothelium. Catravas JD, Gillis CN and Ryan US (eds). Springer, Boston, MA, pp111-120, 1989.

62. Pöschl E, Schlötzer-Schrehardt U, Brachvogel B, Saito K, Ninomiya $Y$ and Mayer U: Collagen IV is essential for basement membrane stability but dispensable for initiation of its assembly during early development. Development 131: 1619-1628, 2004.

63. Goncharov NV, Nadeev AD, Jenkins RO and Avdonin PV: Markers and biomarkers of endothelium: When something is rotten in the state. Oxid Med Cell Longev 2017: 9759735, 2017.

64. Daquinag AC, Zhang Y and Kolonin MG: Vascular targeting of adipose tissue as an anti-obesity approach. Trends Pharmacol Sci 32: 300-307, 2011

65. Lin G, Garcia M, Ning H, Banie L, Guo YL, Lue TF and Lin CS: Defining stem and progenitor cells within adipose tissue. Stem Cells Dev 17: 1053-1063, 2008

66. Sidney LE, Branch MJ, Dunphy SE, Dua HS and Hopkinson A: Concise review: Evidence for CD34 as a common marker for diverse progenitors. Stem Cells 32: 1380-1389, 2014.

67. Zannettino ACW, Paton S, Arthur A, Khor F, Itescu S, Gimble JM and Gronthos S: Multipotential human adipose-derived stromal stem cells exhibit a perivascular phenotype in vitro and in vivo. J Cell Physiol 214: 413-421, 2008.

68. Hu Y, Zhang Z, Torsney E, Afzal AR, Davison F, Metzler B and $\mathrm{Xu}$ Q: Abundant progenitor cells in the adventitia contribute to atherosclerosis of vein grafts in ApoE-deficient mice. J Clin Invest 113: 1258-1265, 2004

This work is licensed under a Creative Commons Attribution-NonCommercial-NoDerivatives 4.0 International (CC BY-NC-ND 4.0) License. 